\title{
THE EFFECT OF ENTREPRENEURIAL BEHAVIOR AND COMPETENCY OF ENTREPRENEURSHIP ON ORNAMENTAL PLANT BUSINESS PERFORMANCE IN BOGOR CITY
}

\author{
Syahroni $^{*}{ }^{1}$, Wahyu Budi Priatna ${ }^{*}$, Burhanuddin*) \\ *Departement of Agribusiness, Faculty of Economic and Management, IPB University \\ Jl. Agatis, IPB Dramaga Campus, Bogor 16680, Indonesia
}

\begin{abstract}
The ornamental plant business is a business dominated by MSEs, so itthat has a vital role in economic development and growth. The largest ornamental plant production center city in West Java Province is Bogor City. This is an opportunity to develop ornamental plant businesses in the town of Bogor, which can be done through the development of entrepreneurial behavior and entrepreneurial competence of ornamental plant entrepreneurs. This study aimed to analyze the effect of entrepreneurial behavior and entrepreneurial competence on ornamental plant business performance in Bogor City. Respondents in this study were 100 ornamental plant entrepreneurs with a total of 100 people who were determined by the convenience sampling method. Data analysis in this study used Structural Equation Model (SEM) with the help of AMOS 23 software. The results showed that entrepreneurial behavior positively and significantly affected ornamental plant business performance with a coefficient value of 0.29 . In addition, entrepreneurial competence also has a positive and significant effect on ornamental plant business performance, with a coefficient value of 0.51 . Thesehis means that every increase in entrepreneurial behavior and entrepreneurial competence will improve the performance of ornamental plants in the city of Bogor.
\end{abstract}

Keywords: business performance, entrepreneurial behavior, entrepreneurial competence, business performance, ornamental plants, structural equation model

\begin{abstract}
Abstrak: Usaha tanaman hias merupakan usaha yang didominasi oleh UMK, sehingga memiliki peranan vital dalam pembangunan dan pertumbuhan ekonomi. Kota sentra produksi tanaman hias terbesar di Provinsi Jawa Barat adalah Kota Bogor. Hal ini menjadi peluang dalam pengembangan usaha tanaman hias di Kota Bogor yang bisa dilakukan melalui pengembangan perilaku kewirausahaan dan kompetensi kewirausahaan pengusaha tanaman hias. Tujuan dalam penelitian ini adalah untuk menganalisis pengaruh perilaku kewirausahaan dan kompetensi kewirausahaan terhadap kinerja usaha tanaman hias di Kota Bogor. Responden pada penelitian ini adalah pengusaha tanaman hias dengan jumlah 100 orang yang ditentukan dengan metode convenience sampling. Analisis data dalam penelitian ini menggunakan Structural Equation Model (SEM) dengan bantuan software AMOS 23. Hasil penelitian menunjukkan bahwa perilaku kewirausahaan berpengaruh positif dan signifikan terhadap kinerja usaha tanaman hias dengan nilai koefisien 0,29. Selain itu, kompetensi kewirausahaan juga berpengaruh positif dan signifikan terhadap kinerja usaha tanaman hias dengan nilai koefisien 0,51. Hal ini berarti setiap peningkatan perilaku kewirausahaan dan kompetensi kewirausahaan akan dapat meningkatkan kinerja usaha tanaman hias di Kota Bogor.
\end{abstract}

Kata kunci: perilaku kewirausahaan, kompetensi kewirausahaan, kinerja usaha, tanaman hias, structural equation model

\footnotetext{
${ }^{1}$ Corresponding author:

Email: ronimenulis@gmail.com
} 


\section{INTRODUCTION}

Ornamental plants are vines, shrubs, or trees planted as part of a greenhouse, home garden, room decoration, ceremony, or flower arrangement. Micro and small-scale enterprises account for the majority of ornamental plant entrepreneurs (MSEs). MSEs have the most economic influence in the Indonesian economy, according to Karunanithy and Jeyaraman (2013), and have proven to be the pillars of the national economy during economic crises and can support post-crisis economic development. As a result, the ornamental plant business is becoming increasingly popular due to its promising future business prospects and the growing popularity of ornamental plants as a hobby. The government also helps with this through the ornamental plant production growth program, which benefits both farmers and entrepreneurs of ornamental plants.

The national market for ornamental plants is showing signs of rising demand. The average positive growth of imports from 2016 to 2020 demonstrates this. Domestic production of ornamental plants also reached more than half a billion stems produced in 2020. North Sumatra, West Java, Central Java, East Java, Banten, and Bali are currently the six provinces in Indonesia that are centercenters for ornamental plant production, according to BPS data (2021). With a production capacity of $8,076,415$ trees, West Java Province has the most potted ornamental plant production. In terms of cutting ornamental flower plants, West Java province is the second-largest producer after East Java, with a production capacity of $183,499,387$ stalks, accounting for $27.04 \%$ of national ornamental plant production in 2020.

Bogor City, in West Java Province, is a center for ornamental plant development. Because of its strategic location and abundance of tourist attractions, Bogor is sometimes referred to as the "City of Tourism." This opens up doors for ornamental plant entrepreneurs to sell their goods to both domestic and international visitors. The City of Bogor's position is challenged by the highly volatile ornamental plant business's production and development. According to BPS data (2020), ornamental plant production increased dramatically in 2015. In 2016, however, the growth in ornamental plant production fell sharply. In 2017, production grew but this was only a small increase compared to a change in 2015. Growth then stabilized, with growth decreasing until 2019.
The growth of ornamental plant businesses is insecure and tends to decline for a variety of reasons, including 1) Ornamental plant businesses in Bogor are clustered near one another, resulting in fierce rivalry; 2) limited access to capital due to private capital source; 3) limited coverage of marketing locations; 4) the status of company ownership is sole proprietorship due to limited access to financial institutions (Tiasmalomo et al. 2020). As a result, it is crucial to investigate the factors needed to improve the performance of ornamental plants in Bogor.

Because business owners have a role in controlling business operations so that business goals are achieved as much as possible, business capabilities and characteristics significantly impact MSEs. In line with that, Amir et al. (2018) and Syam et al. (2020) found that entrepreneurial behavior positively affects business performance. Entrepreneurial behavior is reflected by four indicators: responsiveness to opportunities, innovation, daring to take risks, and active business (Amir et al. 2018). In addition, entrepreneurial competence has a positive and significant influence on business performance. Mustapha et al. (2019) concluded that entrepreneurial competence has a positive and significant impact on the performance of MSMEs in Kelantan, Malaysia. Aliyu (2017) also concludes that entrepreneurial competence has a significant effect on the performance of MSMEs in Nigeria in the Zaria region of the Kaduna local government.

Ornamental plant entrepreneurs with an entrepreneurial spirit will have a positive drive and an optimistic attitude in operating their firm, apply innovation in addressing difficulties, come up with unique ideas, seize opportunities, and dare to take risks when attempting new things. If the owner of an ornamental plant firm has an entrepreneurial spirit, the company will definitely prosper. Some of the preceding statements can be regarded as emphasizing the significance of entrepreneurship in agricultural activities. Several studies have shown that the concept of entrepreneurship, particularly entrepreneurial skill and entrepreneurial behavior, can help business actors improve their performance. As a result, a similar study on ornamental plant enterprises is needed to develop a new approach to evaluate the success of ornamental plant businesses. 
Based on the problems above, this study aims to determine the general description of the ornamental plant business in Bogor. Another research objective is to analyze the effect of entrepreneurial behavior and entrepreneurial competence on ornamental plant business performance in Bogor City. In addition, this study also aims to obtain a policy formulation that can improve the performance of ornamental plants in Bogor.

\section{METHODS}

This study was carried out on a Bogor-based ornamental plant business. The location was chosen with purpose, based on the fact that the decorative plant business in Bogor City is a UMK enterprise that has been operating since 1975 and still thriving and growing. Bogor City, in addition, is the city in West Java with the most significant production of ornamental plants in 2019 , with 144,861 stalks and many ornamental plant entrepreneurs, with a trend of increase in the last five years. The data was collected between October 2020 and January 2021.

Primary and secondary data, both qualitative and quantitative, were used in this analysis. Interviews with target respondents were conducted using a 5-point Likert scale to acquire primary data. Respondent characteristics, entrepreneurialbehavior,entrepreneurial competencies, and business performance make up the preliminary data. Secondary data was gathered from the Central Statistics Agency, the Ministry of Cooperatives and SMEs, literature books, journals, dissertations, theses, the internet, and other sources as reference materials for the study.

The number of participants in this study was at least five times the number of manifest variables used, and the respondents ranged from 100 to 200 (Ferdinand 2002). To meet the required sample size, the number of respondents in this study must be greater than or equal to 100 ornamental plant entrepreneurs. Initially, primary random sampling was used to determine who would respond. However, some employers refuse to be questioned again, resulting a change in respondents' decisions, which are based on convenience and ease of data collection factors.
The information gathered in this study was evaluated using descriptive methods, such as quantitative and qualitative descriptive analysis, and multivariate analysis, such as Structural Equation Modeling (SEM). Descriptive analysis to provide a broad description of the ornamental plant business conditions in Bogor. On the other hand, the SEM analysis seeks to uncover correlations between research variables, both latent and explicit.

Interview techniques and a questionnaire were used to conduct descriptive analysis. Class interval calculations or interval widths will be used to calculate interpretation criteria for the average score on the responses in the questionnaire. Because the greatest score is 5 and the lowest is 1 , the range is $\mathrm{R}=5-1=4$, yielding a wide range of $\mathrm{k}=4 / 5=0.8$. The responses in the questionnaire are interpreted as follows: $1.00-1.8=$ extremely low; 1.8-2.6 = low/poor; 2.6-3.4 = moderate; $3.4-4.2=$ high/ good; $4.2>=$ very high/very good.

Furthermore, data analysis utilizing the AMOS technique employing the Structural Equation Model (SEM). SEM AMOS will generate a number of solutions to equations relating the variances and covariances of observed variables (manifest/indicators) to model parameters (Ghozali, 2017). There are seven steps to developing an SEM model: developing a theoretical model, developing with path diagrams, converting flowcharts into structural equations, determining the input matrix and model estimation, estimating model coefficients, evaluating the goodness of fit criteria, and interpreting and modifying the model. In addition, validation tests based on the average variance extracted (AVE) value and a model reliability test based on construct reliability $(\mathrm{CR})$ were performed on the SEM model.

There are two types of variables in this study, namely latent variables and manifest variables. Latent variables consist of exogenous latent and endogenous latent. Exogenous latent is a variable of entrepreneurial behavior and entrepreneurial competence, while endogenous latent is a variable of business performance. The entrepreneurial variable is defined as a learning process from the interaction of entrepreneurs in running a business as measured by responsiveness to opportunities, innovation, risk-taking, and trying hard. The entrepreneurial competence variable is defined as the entrepreneurial activity of ornamental plant entrepreneurs to create value as measured by leadership and skills. The performance variable is defined as the work of entrepreneurs to achieve business goals as 
measured by increased income, increased workforce, business ownership, competitive advantage, and expansion of the marketing area. The variables that measure the latent variable are defined as manifest variables. The manifest and latent variables can be used correctly because they are based on empirically validated theories used in the field. Table 1 shows the rundown of latent variables and manifest variables.

The hypothesis of this study is based on previous research that shows that entrepreneurial behavior and competence have a positive and important impact on business success. This type of influence is most prevalent in micro and small businesses. Entrepreneurial behavior has been found to have a beneficial relationship with business success in the ornamental plant business. Burhanuddin and Ramadhan (2019) found that entrepreneurial skill has a huge impact on the success of micro and small-scale enterprises. Entrepreneurial behavior and competence are expected to make ornamental plant entrepreneurs more proactive, imaginative, inventive, intelligent, and have a leadership spirit when it comes to running a company. As a result, the hypotheses tested in this analysis are that (1) entrepreneurial activity has a positive and significant impact on ornamental plant performance, and (2) entrepreneurial skill has a positive and significant impact on ornamental plant business performance.

This study uses an entrepreneurial approach to investigate the success and development of decorative plantenterprises in Bogor City, as shown in Figure 1. This study used two factors to investigate entrepreneurship: entrepreneurial behavior and entrepreneurial skill for ornamental plant entrepreneurs in Bogor. Using the SEM model, the effect will also be explored on the performance of ornamental plants in Bogor. In addition, descriptive analysis is used to investigate the general description of the ornamental plant business in Bogor City. Finally, the research findings using the SEM model and descriptive analysis should result in a policy formula that can improve the performance of ornamental plants in Bogor.

\section{RESULTS}

\section{Overview of Ornamental Plant Business in the City of Bogor}

The government oversees most ornamental plant businesses in Bogor through the Bogor City Cooperative and the MSMEs' Office. On Dadali and Ringroad 3 streets, the ornamental plant businesses are strewn around. The benefit of having a coached ornamental plant business is that the ornamental plant business kiosk will reduce the risk of being relocated or disciplined by the Bogor City government. If there are government programs related to MSMEs' growth, particularly the ornamental plant business, the fostered ornamental plant business would receive more government attention. Furthermore, on Semeru and Padjajaran streets, there are ornamental plant businesses that the government does not subsidize. According to a businessman whose business status is not regulated by the Bogor City government, these entrepreneurs pay a rental fee to set up a kiosk in the town. Non-assisted ornamental plant companies, on the other hand, face a very high risk of being disciplined or relocated by the Bogor City government in the future.

Table 1. Latent variable and manifest variable

\begin{tabular}{lll}
\hline Latent variable & Manifest variable & Theoretical basis \\
\hline $\begin{array}{l}\text { Exogenous latent variables of } \\
\text { entrepreneurial behavior (PK) }\end{array}$ & Responsiveness to opportunities (PK1) & $\begin{array}{l}\text { Nursiah et al. (2015); Puspitasari et } \\
\text { al. (2018); Riyanti (2003); Ropega }\end{array}$ \\
& Innovative (PK2) & (2016); Syam et al. (2020); Zainura et \\
Taking risks (PK3) (2016) & \\
& Diligent effort (PK4) & Schenkel et al. (2019); Spenser and \\
Exogenous latent variable of & Leadership (KK1) & Spencer (1993) \\
entrepreneurship competence (KK) & Skills (KK2) & Darmadji (2014); Riyanti (2003); \\
Endogenous latent variables of & Expansion of business scale (KU1) & Martauli et al. (2016); Praag and \\
business performance (KU) & Income increase (KU2) & Versloot (2008); Puspitasari et al. \\
& Increase in the workforce (KU3) & (2018) \\
& Business Ownership (KU4) & \\
\hline
\end{tabular}




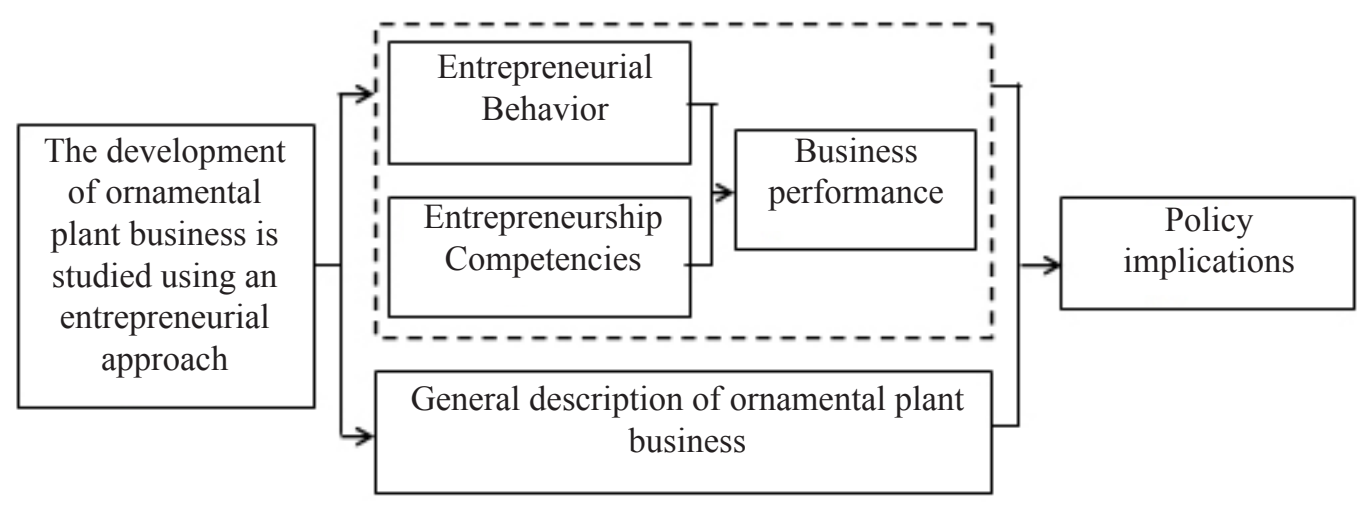

Figure 1. Research framework

Entrepreneurs selling ornamental plants in Bogor City also mostly market and distribute their products offline (face-to-face). This illustrates that ornamental plant entrepreneurs in Bogor only have a limited opportunity to embrace creativity and technology. Ornamental plant entrepreneurs say that only marketing activities at ornamental plant stalls using banner media in front of the ornamental plant stalls satisfy them. This also demonstrates that the marketing efforts of ornamental plant entrepreneurs in Bogor are still ineffective. The demand for ornamental plant products is still thin, making it difficult to optimize profits.

\section{Entrepreneurial Behavior of Ornamental Plant Entrepreneurs}

Entrepreneurial conduct refers to an entrepreneur's attitudeandactionsinmanaging theircompany,including gathering information, observing opportunities, taking risks, and several other factors. The responsiveness of ornamental plant entrepreneurs to market opportunities, the willingness to innovate, the courage of ornamental plant entrepreneurs to take risks, and the persistence of ornamental plant entrepreneurs in running their business are factors in determining their entrepreneurial conduct. With an average of 4.12 (average $>3.4$, which means high/good), entrepreneurial activity was found to be in the high/good category. The entrepreneur's willingness to take risks is a high-standard indicator, so this indicator affects. The most comprehensive study of ornamental plant entrepreneurs' entrepreneurial behavior in Bogor. This suggests that entrepreneurs in the ornamental plant business respect entrepreneurial skills.

\section{Ornamental Plant Entrepreneurship Competencies}

Entrepreneurial competence refers to an entrepreneur's ability to create new value to grow a company. By stressing job capacity, entrepreneurial competence may also describe the skills or expertise that entrepreneurs possess. The entrepreneurial competence of ornamental plant entrepreneurs was evaluated using leadership and ability measures in this report. With an average of 3.75 (average $>3.4$, which means high/good), ornamental plant entrepreneurs' entrepreneurial competence was classified as high/good. Leadership indicators are held to the highest level, allowing them to assess entrepreneurial capacity. Bogor City's ornamental plant entrepreneurs wield more power. This suggests that ornamental plant business owners believe that having entrepreneurial skills will help them succeed.

\section{Ornamental Plant Business Performance}

The acquisition of outcomes from running a company to maximize profit is known as business success. This study's company's success is evaluated in terms of scale growth, increased profits, increased workforce, business ownership, and competitive advantage. The findings revealed that ornamental plant entrepreneurs' expectations of their businesses' success are moderate (average $2.6>-3.4$, which means moderate). As a result of the help of entrepreneurial behavior variables and entrepreneurial competency variables currently possessed by ornamental plant entrepreneurs, the ornamental plant business's success in Bogor City has increased moderately. An increase in labour, a competitive advantage, and an increase in profits are all measures of a high/good group average (average> 3,4, which means high/good). These metrics play a significant role in assessing the success of Bogor City's ornamental plant businesses. 


\section{Measurement Model Analysis (Outer)}

A path diagram is used to evaluate the causality relationship between variables in an SEM model. After that, the model is calculated to obtain a value or coefficient in the form of regression weight. The closeness of the relationship between variables can be shown by regression weight. The loading factor generated by the SEM model indicates how strongly the manifest variable represents the latent variable. Furthermore, the model as a whole must follow a high standard (good fit) and meet the cut-off value requirement. P-value greater than 0.05, Chi-Square / DF less than 2, GFI greater than 0.90, AGFI greater than 0.90 , TLI greater than 0.95 , CFI greater than 0.95 , and RMSEA greater than 0.08 to 0.05 are the cut-off value measures (Arbuckle and Wothke, in Solimun et al. 2017).

The initial research model, as a result, does not reach the cut-off value and has a bad fit. As a result, the model must be tweaked to achieve the best results. A path diagram between the two error variances and a path diagram between the manifest variables are used to modify the model (Table 2). The effect of model alteration is a model that is superior to the original model (Figure 2).

Table 2. Goodness of fit in the modified model

\begin{tabular}{lccc}
\hline Size GOF & Cut-off Value & Result & Information \\
\hline (Goodness of Fit) & Small value & $\mathrm{x}^{2}=22.764$ & Good fit \\
Chi-Square & Value $\leq 2.00$ & CMIN/Df $=0.71$ & Good fit \\
CMIN/Df & Value $\mathrm{p} \geq 0.05$ & $\mathrm{P}=0.89$ & Good fit \\
P-value & & & Good fit \\
Root Mean Square Error of Approximation (RMSEA) & Value $\leq 0.08$ & RMSEA $=0.00$ & Good fit \\
Goodnesss of Fit Index (GFI) & Value $\geq 0.90$ & GFI $=0.96$ & Good fit \\
Normed Fit Index (NFI) & Value $\geq 0.90$ & NFI $=0.96$ & Good fit \\
Tucker Lewis Index (TLI) & Value $\geq 0.90$ & TLI $=1.03$ & Good fit \\
Comparative Fit Index (CFI) & Value $\geq 0.95$ & CFI $=1.00$ &
\end{tabular}

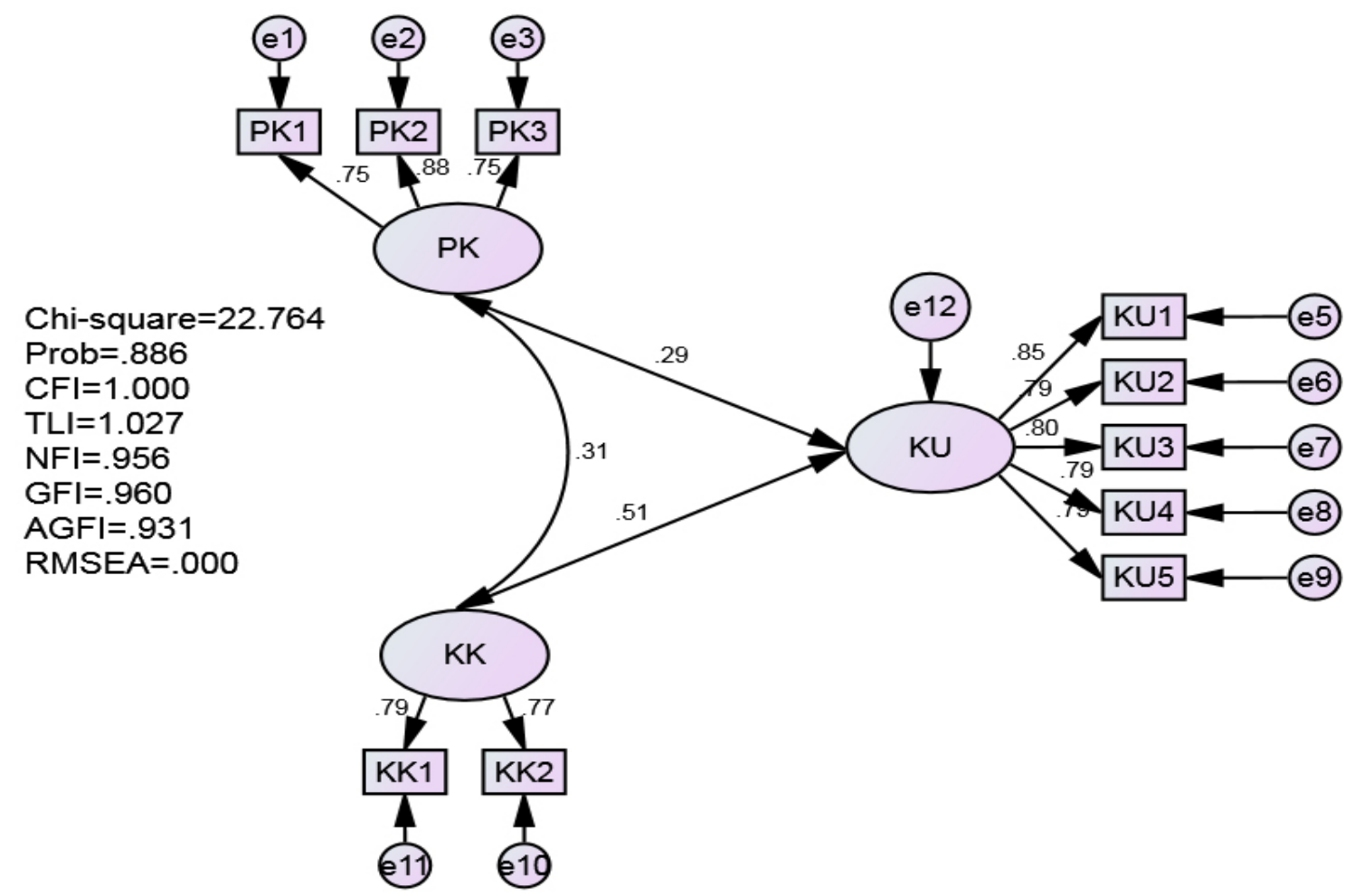

Figure 2. The results of the modification of the model and the estimation of the goodness of fit 


\section{Construct Reliability}

The indicator's reliability is measured as the next evaluation test. The construct reliability (CR) value and the average variance extracted (AVE) value determine indicator reliability. Each latent variable has a good CR value greater than 0,7 , as shown in Table 3. Not all latent variables have a strong criterion value or a value greater than 0,5 at the AVE value, but these results are similar to the minimum criteria. The findings are comparable to the model's reliability test before modification.

\section{Structural Model Analysis (Inner)}

Table 4 illustrates that the structural model of entrepreneurial behavior's evaluation results positively and significantly impact business performance. Furthermore, entrepreneurial skill has a significant and positive impact on business performance. With a $\mathrm{t}$-value $>1.96$, the path coefficients of the PK and KK variables have a direct effect directly impact KU. Table 27 illustrates that the structural model of entrepreneurial behavior's evaluation results has positively and significantly impacted business performance. Furthermore, entrepreneurial skill has a significant and positive impact on business performance. With a t-count value $>1.96$, the path coefficients of the PK and KK variables have a direct effect directly impact KU. As a result, we may infer that this research hypothesis is valid.

\section{The Influence of Entrepreneurial Behavior and Entrepreneurial Competence on the Performance of Ornamental Plants in the City of Bogor}

The findings (Table 4) revealed that ornamental plant entrepreneurs' entrepreneurial behavior and competence positively impacted ornamental plant business success. This means that ornamental plant entrepreneurs' increasing and evolving entrepreneurial actions and entrepreneurial competence would boost the ornamental plant company's performance. In the entrepreneurial behavior variable, it can be explained that the responsiveness to the opportunities that the ornamental plant entrepreneurs have, the innovation efforts made by the ornamental plant entrepreneurs, the courage to take risks that the ornamental plant entrepreneurs have, and the business persistence possessed by ornamental plant entrepreneurs in managing their business will ultimately affect improving the performance of ornamental plants business. In the entrepreneurial competence variable, improving ornamental plant entrepreneurs' potential to lead their businesses and increasing their abilities will also help the ornamental plant company perform better. This is in line with the findings of Ramadhan (2017), who studied purebred chicken breeders and found that breeders' entrepreneurial behavior and entrepreneurial competence influenced the success of broiler farm businesses.

Table 3. The results of the measurement model reliability test

\begin{tabular}{lcccccc}
\hline Latent Variable & $(\Sigma \text { std Load })^{2}$ & $\Sigma \mathrm{ej}$ & $\mathrm{CR}$ & $\Sigma$ (std Load $^{2}$ & AVE & Description \\
\hline Entrepreneurial behavior & 5.67 & 1.10 & 0.84 & 1.90 & 0.63 & Reliabel \\
Entrepreneurial competence & 2.42 & 0.79 & 0.75 & 1.21 & 0.61 & Reliabel \\
Business performance & 16.15 & 1.77 & 0.90 & 3.23 & 0.65 & Reliabel \\
\hline
\end{tabular}

Table 4. Estimated values and significance of the structural model

\begin{tabular}{|c|c|c|c|c|}
\hline \multirow{2}{*}{ Variable } & \multicolumn{2}{|c|}{ Path Coefficients } & \multirow[t]{2}{*}{ t-value } & \multirow{2}{*}{ Conclusions } \\
\hline & Direct & Indirect & & \\
\hline $\mathrm{PK} \rightarrow \mathrm{KU}$ & 0.29 & - & 2.66 & Significant and positive \\
\hline $\mathrm{KK} \rightarrow \mathrm{KU}$ & 0.51 & - & 4.01 & Significant and positive \\
\hline
\end{tabular}


The study results indicated that the entrepreneurial behavior variable had a substantial effect on the output of ornamental plants in Bogor, as big as 29 percent (loading factor 0.29). The manifest variable that has a contribution influence in reflecting the entrepreneurial behavior factor is innovating with a power of 88 percent (loading factor 0,88 ). Based on this, increasing the innovation ability of ornamental plant entrepreneurs, especially in terms of producing innovative products more efficiently, can stimulate an increase in the entrepreneurial behavior of ornamental plant entrepreneurs, so that this increase will affect the performance of ornamental plant businesses. This value is higher than the coefficient value of other manifest variables' effect on entrepreneurial behavior, which is also measured. Ornamental plant entrepreneurs have a variety of ornamental plant products in terms of type, colour, scale, and shape, according to field data. The variety of ornamental plants grown by ornamental plant entrepreneurs is similar, so there is little that separates one ornamental plant enterprise from another in terms of uniqueness. This is due to ornamental plant entrepreneurs' inability to add value to their products and their lack of imagination. Certain marketing, production, and management methods that have been developed have not been widely adopted. Amir et al. (2018) came to the same conclusion, arguing that the variable that most strongly reflects entrepreneurial activity is innovation.

The second indicator that has the most significant contribution in measuring entrepreneurial behavior is the risk-taking indicator of 75 percent (loading factor 0.75). Ornamental plant business owners face various challenges, including fluctuating demand, which puts their profits at risk. Furthermore, it will introduce site control for ornamental plant entrepreneurs whose location is not within the Bogor City Cooperative and MSMEs' Office's target area, forcing them to relocate. The entrepreneurial process is one of the critical variables that affect the survival of small businesses during periods of economic crisis (Ropega, 2016). Maron et al. (2019) makes the same point: entrepreneurs in MSMEs can maintain business continuity due to their tendency always to take higher risks.. According to Zainura et al. (2016), entrepreneurial behavior is critical in improving company efficiency, risk-taking, and business perseverance.

In addition, other indicators that also have a positive and significant contribution in reflecting entrepreneurial behavior are indicators of responsiveness to opportunities. The indicator of responsiveness to possibilities has a positive and significant effect of 75 percent (loading factor 0.75). This means that the ability of entrepreneurs to seize opportunities in developing ornamental plant businesses will greatly determine entrepreneurial behavior in running their business. Responsiveness to prospects can be shown by increasing promotional activities carried out by ornamental plant entrepreneurs, which will increase entrepreneurial behavior which will ultimately improve the performance of the ornamental plant business. Zainura (2016) and Amir (2017) also mention that responsiveness to opportunities is an indicator that has a positive and significant influence in reflecting entrepreneurial behavior.

The analysis results also show that the entrepreneurial competence variable can significantly influence the performance of the ornamental plant business by 51 percent. This means that the increase in entrepreneurial competence as measured by the leadership and skills possessed by ornamental plant entrepreneurs can improve the performance of the ornamental plant business. The manifest variable that has the most significant contribution in reflecting entrepreneurial competence is leadership, with a power of 79 percent (loading factor 0.79). Based on this, the more often ornamental plant entrepreneurs provide constructive criticism and suggestions to employees, it will increase the entrepreneurial competence of ornamental plant entrepreneurs. In the end, it will improve the performance of the ornamental plant business. The same thing was explained by Ramadhan (2017), who took farmers as respondents that leadership abilities were able to produce good business performance. The facts in the field also show that before starting work, ornamental plant entrepreneurs will provide work directions, suggestions, and criticisms to their employees, especially for new employees. The hope of ornamental plant entrepreneurs with work directions, constructive criticism, and offers can encourage employees to provide the best performance.

Furthermore, the manifest skill variable also has a significant contribution in assessing entrepreneurial competence by 77 percent. This means that increasing the interest of ornamental plant entrepreneurs would boost their skills, thus improving the ornamental plant market's success. Plant entrepreneurs are fascinated by successful cultivation techniques for different types of 
ornamental plants and the preferences of ornamental plant consumers or buyers. A high level of interest will result in new knowledge that will help the growth of entrepreneurial skills. Lackeus et al. (2016) define entrepreneurial competence as "awareness, skills, and attitudes that influence one's willingness and ability to do entrepreneurial work to generate new value."

\section{Managerial Implications}

The findings show that entrepreneurial behavior has a positive and important impact on ornamental plants' performance in Bogor. As a result, the entrepreneurial activity involves being receptive to opportunities, being creative, taking risks, and working tirelessly to enhance the ornamental plants' efficiency. This becomes a suggestion to the Bogor City government to develop initiatives that will continue to promote ornamental plant entrepreneurs' entrepreneurial activity. To expand opportunities for the growth of ornamental plant businesses, the Bogor City Government must also have easy market access.

Furthermore, in Bogor, entrepreneurial expertise has an important and positive influence on the performance of ornamental plants. Entrepreneurial competence metrics, such as leadership and knowledge, have a huge effect on promoting ornamental plant business performance growth. This means that the Bogor City government must also improve the leadership and skills of ornamental plant entrepreneurs. Management preparation, apprenticeship programs, and comparative research programs are examples of steps that can be taken to strengthen the leadership spirit of ornamental plant entrepreneurs. Aside from leadership, ornamental plant entrepreneurs' skills must be enhanced, for example, by agricultural counselling, business capital assistance, and coaching incentives for ornamental plant management from upstream to downstream.

A stimulus from the Bogor City government is also needed to increase technological innovation among ornamental plant entrepreneurs in Bogor City, which can be accomplished through training and promotional assistance. This training would indirectly motivate the city of Bogor to enhance the output of ornamental plants. Government-owned properties used as ornamental plant business locations still have government ownership status, allowing for evictions or take-home orders. As a result, legal certainty in the area used as a business location for ornamental Bogor plants is needed.
This research is limited to the assessment of perceptions of entrepreneurial behavior and entrepreneurial competence of ornamental plant entrepreneurs in the city of Bogor and how it affects the performance of ornamental plants in the town of Bogor, so the results of this study cannot conclude the conditions in other areas. Ornamental plant entrepreneurs in question are ornamental plant entrepreneurs who sell directly to consumers of ornamental plants without intermediary traders.

\section{CONCLUSIONS AND RECOMMENDATIONS}

\section{Conclusions}

Based on the excellent fit estimation of the SEM model, it can be concluded that the entrepreneurial behavior of ornamental plant entrepreneurs has a positive and significant effect on the success of ornamental plant businesses in Bogor City. Responsiveness to opportunities, innovativeness, and courage to take risks are indicators that can reflect entrepreneurial behavior. Entrepreneurial competence also has a positive and significant influence on the performance of ornamental plant businesses in Bogor. When compared with entrepreneurial behavior, entrepreneurial competence has a more dominant effect. Indicators of leadership and skills measure entrepreneurial competence.

\section{Recommendations}

Further research could look into factors that affect entrepreneurial actions, such as internal and external environmental factors, as well as ornamental plant entrepreneurs' entrepreneurial competence, such as technical competencies and entrepreneurs' technical competencies. Furthermore, additional research may include other entrepreneurial factors that influence the performance of ornamental plants, such as entrepreneurial orientation and entrepreneurial activities.

\section{REFERENCES}

Aliyu MS. 2017. Entrepreneurial competencies and the performance of small and medium enterprises (SMEs) in zaria local government area of Kaduna State. International Journal of Entrepreneurial Development, Education and Science Research 
(IJEDESR) 4(2):116-138.

Amir RM, Burhanuddin, Priatna WB. 2018. The effect of individual, environmental and entrepreneurial behavior factors on business performance of cassava SMEs agroindustry in Padang City. Indonesian Journal of Business and Entrepreneurship 4(1):1-10.

[BPS] Badan Pusat Statistik. 2021. Statistik Tanaman Hias Indonesia. Indonesia:BPS.

Burhanuddin, Ramadhan RP. 2019. The influence of farmer entrepreneurial competence on broiler farm performance in Bogor. Jurnal Manajemen \& Agribisnis 16(2):170-180.

Darmadji. 2014. Analisis kewirausahaan sebagai variabel baru penentu kinerja usahatani dan pengujiannya melalui model SEM (Structural Equation Models). Jurnal Agritop, Ilmu-ilmu Pertanian 12(1):40-49.

Ferdinand, A. 2002. Structural Equation Modelling dalam Penelitian Manajemen. Semarang:Badan Penerbit UNDIP.

Ghozali I. 2017. Model Persamaan Struktural Konsep dan Aplikasi dengan Program AMOS 24 Update Bayesian SEM. Semarang:Badan Penerbit Universitas Diponegoro.

Karunanithy K, Jeyaraman S. 2013. Impact of entrepreneurial characteristics on the organizational development of the small business entrepreneurs. Industrial Engineering Letters 3(6):28-33.

Lackeus M, Lundqvist M, Middleton KW. 2016. Bridging the traditional progressive education rift through entrepreneurship. International Journal of Entrepreneurial Behavior \& Research 22(6):777-803.

Maron S, Lussier RN, Sonfield M. 2019. Entrepreneurial strategy:The relationship between firm size and levels of innovation and risk in small businesses. Journal of Small Business Strategy 29(3):3345.

Martauli ED, Baga LM, Fariyanti A. 2016. Faktorfaktor yang berpengaruh terhadap kinerja usaha wanita wirausaha kerupuk udang di Provinsi Jambi. Jurnal Agraris 2(2):118-127.

Mustapha WNW, Mamun AA, Mansori S, Balasubramaniam S. 2020. Effect of entrepreneurialcompetenciesonmicroenterprises income and assets in Malaysia. Asia Pacific Journal of Innovation, and Entrepreneurship 14(3):249-261.
Nursiah T, Kusnadi N, Burhanuddin. 2015. Perilaku kewirausahaan pada usaha mikro kecil (UMK) Tempe di Bogor Jawa Barat. Jurnal Agribisnis Indonesia 3(2):145-158.

Praag CM, Versloot PH. 2008. The economic benefits and costs of entrepreneurship:a review of the research. Foundations and Trends in Entrepreneurship 4(2):65-154.

Puspitasari, Nurmalina R, Fariyanti A, Kiloes AM. 2018. Pengaruh faktor internal dan eksternal terhadap perilaku kewirausahaan dan dampaknya terhadap kinerja usaha petani anggrek. Jurnal Hortikultura 28(2):299-310.

Ramadhan RP. 2017. Pengaruh perilaku kewirausahaan dan kompetensi kewirausahaan peternak terhadap kinerja usaha peternakan ayam ras pedaging di Kabupaten Bogor. [tesis]. Bogor:Institut Pertanian Bogor.

Riyanti BP. 2003. Kewirausahaan Dari Sudut Pandang Psikologi Kepribadian. Jakarta:PT Grasindo.

Ropega J. 2016. Entrepreneurial behavior in periods of deterioration of small firms' condition. Entrepreneurial Business and Economics Review 4(2):139-156. http://dx.doi.org/10.15678/ EBER.2016.040211

Schenkel MT, Farmer S, Maslyn JM. 2019. Process improvement in SMEs:the impact of harmonious passion for entrepreneurship, employee creative self-efficacy, and time spent innovating. Journal of Small Business Strategy 29(1):71-84.

Spenser LM, Spencer SM. 1993. Competence at Work:Models for Superior Performance. New York:John Wiley \& Sons, Inc.

Solimun, Fernandes AAR, Nurjannah. 2009. Metode Statistika Multivariat Pemodelan Persamaan Struktural (SEM) Pendekatan WarpPLS. Malang:UB Press.

Syam AH, Pambudy R, Priatna AB. 2020. The effects ofentrepreneurial behavior on seaweed business performance in Takalar Regency. Jurnal Manajemen \& Agribisnis 17(2):196-206.

Tiasmalomo R, Rukmana D, Mahyudin. 2020. Analisis positioning pelaku usaha tanaman hias di Kota Makassar. Jurnal Ilmiah Indonesia 5(6):158171.

Zainura U, Kusnadi N, Burhanuddin. 2016. Perilaku kewirausahaan petani kopi arabika gayo di Kabupaten Bener Meriah Provinsi Aceh. Jurnal Penyuluhan 12(3):126-143. 